\title{
Hermaphroditism in Marine Mussel Perumytilus purpuratus (Lamarck, 1819), (Mollusca: Mytilidae)
}

\author{
Hermafroditismo en el Chorito Perumytilus purpuratus (Lamarck, 1819), (Mollusca: Mytilidae)
}

*Diana Montenegro Villalobos; **Alberto Olivares Paz \& *María Teresa González

MONTENEGRO, V. D.; OLIVARES, P. A. \& GONZÁLEZ, M. T. Hermaphroditism in marine mussel Perumytilus purpuratus (Lamarck, 1819), (Mollusca: Mytilidae). Int. J. Morphol., 28(2):569-573, 2010.

SUMMARY: Marine bivalves are essentially gonochoric species. However, some occasional hermaphrodites specimens can be found. A histological description of two (among 179) hermaphrodites of the marine mussel Perumytilus purpuratus (Lamarck, 1819) that were collected in San Jorge Bay $\left(24^{\circ} \mathrm{S}\right)$ is given. The low proportion of hermaphrodites suggests that P. purpuratus hermaphroditism could be an accidental phenomenon; nevertheless other causes are also discussed in the present study.

KEY WORDS: Bivalve; Hermaphroditism; Perumytilus purpuratus.

\section{INTRODUCTION}

Bivalves (also known as lamellibranchs or pelecypods) include groups such as clams, mussels, scallops, and oysters (Brink, 2001). Among the more than 10,000 species belonging to the class Pelecypoda may be found in different degrees of sexual differentiation from species that are strictly of separated sexes in relations to those that are almost invariably functionally hermaphroditic (Coe, 1943). Especially, freshwater bivalves are often hermaphroditic (Morton, 1991). However, hermaphroditic individuals occasionally have been found in species strictly considered gonochoric (Heller, 1993), such as clams Ruditapes decussatus (L.) (Delgado \& Perez, 2002), Anadara granosa (L.) and Anadara Antiqua (L.), which have simultaneously male and female tissue in the same follicle (Afiati, 2007). Similarly, Ceuta et al. (2007) recorded hermaphroditism in two clams species Tagelus plebeius (Lightfoot, 1786) and Iphigenia brasiliana (Lamark, 1818), Vinuesa (1977) reported the first hermaphrodite in mussel Aulacomya ater (Molina) and Villalon (1965) reported one of 4309 (0.023\%) specimen of Perumytilus purpuratus (Lamarck, 1819) with male and female gonads.

Perumytilus purpuratus is a common marine mussel in the rocky intertidal habitats from Ecuador to Strait of
Magellan, extending up to the Atlantic coast of Santa Cruz, Argentina. This specie is diocious, the female mantle is brown and the mantle of male is yellow (Osorio \& Bahamonde, 1968; Paredes \& Tarazona, 1980).

In the present paper, a histological description as an evidence of hermaphroditism in Perumytilus purpuratus from the Northern Chilean coast is recorded.

\section{MATERIAL AND METHOD}

Between September and November 2009, at low tides, 179 specimens of Perumytilus purpuratus were collected in lower intertidal layer along the coastal area of San Jorge Bay. The specimens were measured by using a digital caliper (precision $0.01 \mathrm{~mm}$ ). Taking into account that reproductive tissue in mytilids expand and invade soft tissues in the visceral mass and mantle lobes (Field, 1922), sex was determined based on gonad tissue color and the mantle: male (Fig. 1), female (Fig. 2) and in the case of the hermaphrodites specimens, one lobe of the mantle was browner and the other was yellow (Fig. 3). Hermaphrodites were found in intertidal

\footnotetext{
* Instituto de Investigaciones Oceanológicas. Facultad de Recursos del Mar, Universidad de Antofagasta, Casilla 170, Antofagasta, Chile.

** Departamento de Acuicultura. Facultad de Recursos del Mar, Universidad de Antofagasta, Casilla 170, Antofagasta, Chile.
} 


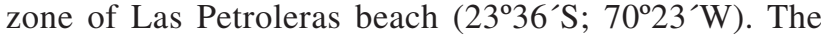
gonads were fixed with Davidson solution, dehydrated, embedded in paraplast, sectioned at $5 \mu \mathrm{m}$ with Microtome Minot and stained with haematoxylin and eosin (Bancroft \& Steves, 1990).

\section{RESULTS AND DISCUSSION}

Mussel sizes varied from $27.77 \mathrm{~mm}$ to $38.72 \mathrm{~mm}$. The size frequency is shown in Table I. The lengths of hermaphrodite mussels were $34.18 \mathrm{~mm}$ and $29.5 \mathrm{~mm}$. The proportion of sexes did not differ from 1:1 (c2=6.635; $\mathrm{p}<$ 0.01) Zar (1996).

In the general structure of male gonads in $P$. purpuratus, the testis are formed by seminiferous follicles (Fig. 4), whose epithelium contains spermatogenic cells, organized in layers, and Sertoli cells (Pipe, 1987). In female, the ovary is organized by gonadal follicles (See figure 5); with mature oocytes inside of them (Mykhalow et al., 1995). Hermaphrodites presented in the testis, follicles with fully mature sperm and other follicles with total emission of male gametes but in the stratum basale a reduced number of oocytes (Figs. 6 and 7). In summary the presence of male follicles in the lumen and the presence of oocytes, are evidences of a hermaphroditism in mussels Perumytilus purpuratus.

Other cases of occasional hermaphroditism in mollusks have been recorded in Cephalopods (Ortiz \& Re, 2006), Polyplacophora (Scarano \& Ituarte, 2009), and Gastropoda (Olivares et al., 2009). The scarce records of hermaphrodite individuals indicate that it could be an accidental phenomenon (Calvo et al., 1998); however, mechanisms of sexual differentiation control are not absolutes. Beninger \& Le Pennec (1991) mentioned that it is possible to find low frequency of hermaphrodite specimens, even within gonochoric species. In the similar line, Coe suggested that these occasional individuals with functional hermaphroditism can all be considered as a result from deviations in developmental processes, due to the failure of the sex differentiating mechanism to function normally.

The endocrine systems of invertebrates generally regulate the same processes that are found in vertebrates such as development, growth, and reproduction (Oehlmann \& Shutlte-Oehlmann, 2003). Several compounds or groups are known to disrupt specific invertebrate endocrine systems, including development and reproductive function (Defur, 2004). Endocrine disruptors include organotin, organichlorine, pesticides, industrial chemical (biphenyls and polycyclic aromatic hydrocarbons) (Lintelmann et al., 2003). Some authors have found incidence of ovotestis (produce eggs and sperm) in bivalves, which suggest that associations with urban, industrial, or organotin presence could be established. However, they indicate that the mode of action remains largely unclear (Chesman \& Langston, 2006; Horiguchi et al., 2000; Langston et al., 2007; Petridis et al., 2009). In our study the hermaphrodites (ovotestis) were found in a polluted location by polycyclic aromatic hydrocarbons and heavy metals (Salamanca et al., 2004; CREA, 2005). Despite this, more evidence is needed to confirm that this hermaphroditism is related to pollution.

In conclusion, evidence of hermaphroditism in Perumytilus purpuratus is recorded. Although these hermaphrodite specimens could be an occasional occurrence in Perumytilus purpuratus and additional studies will be necessary to link them to pollution, endocrine disruption and the sexual development of the mussel Perumytilus purpuratus.

Table I. Frequencies of Perumytilus purpuratus by sex and size classes (mm).

\begin{tabular}{lcccccc}
\hline & & Male $(\mathrm{M})$ & & Female $(\mathrm{F})$ & \multicolumn{2}{c}{ S exual proportion } \\
\hline Size Class & $\mathrm{n}$ & $\%$ & $\mathrm{n}$ & $\%$ & $\mathrm{M} / \mathrm{F}$ & $\mathrm{C}^{2}$ \\
$27.70-28.81$ & 1 & 0.9 & 1 & 1.3 & 1.00 & 2.00 \\
$28,82-29,93$ & 10 & 9.8 & 6 & 8 & 0.50 & 1.00 \\
$29.94-31.05$ & 11 & 10.78 & 10 & 13.33 & 0.02 & 0.05 \\
$31.06-32.17$ & 18 & 17.65 & 10 & 13.33 & 1.14 & 2.29 \\
$32.18-33.29$ & 15 & 14.71 & 10 & 13.33 & 0.50 & 1.00 \\
$33.3-34.41$ & 17 & 16.66 & 14 & 18.67 & 0.15 & 0.29 \\
$34.42-35.53$ & 7 & 6.86 & 8 & 10.67 & 0.03 & 0.07 \\
$35.54-36.65$ & 10 & 9.8 & 7 & 9.33 & 0.26 & 0.53 \\
$36.66-37.77$ & 11 & 10.78 & 6 & 8 & 0.74 & 1.47 \\
$37.78-38.89$ & 2 & 1.96 & 3 & 4 & 0.10 & 0.20 \\
\hline
\end{tabular}



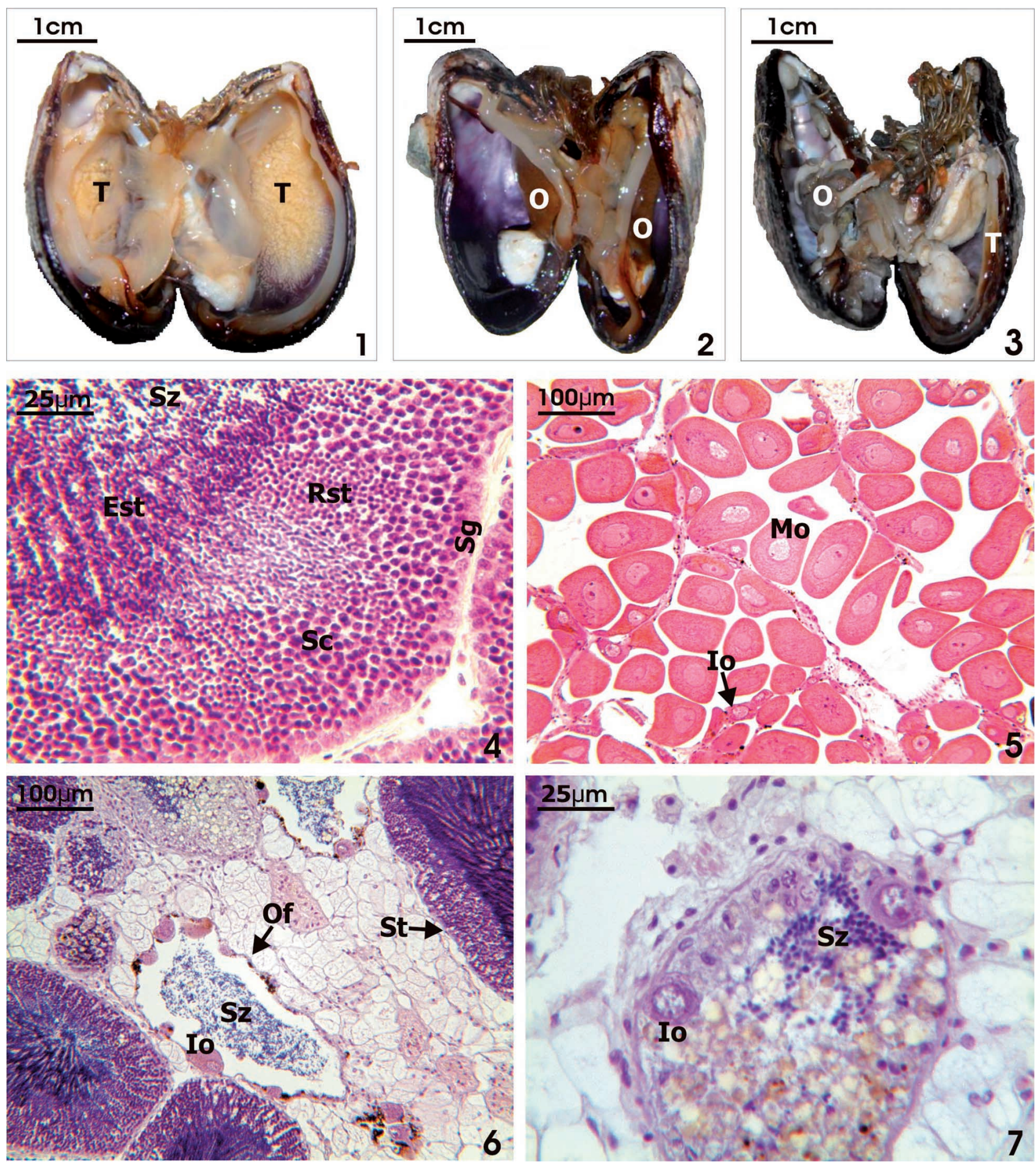

Figs. 1-3. Observation of specimens male (Fig. 1), female (Fig. 2) and hermaphrodite (Fig. 3) of Perumytilus purpuratus: T: testis; O: ovary.

Figs. 4-7. Gonadal histology of Perumytilus purpuratus. Stain Hematoxilene \& Eosine.

Fig. 4. Observation of mature seminiferous tubule. Spermatogonia (Sg), Spermatocyte (Sc). Round spermatid (Rst). Elongated spermatid (Est) and spermatozoa (Sz).

Fig. 5. Ovarian follicle with a high number of mature oocytes (Mo), and immature oocytes (Io).

Figs. 6 y 7. Gonads of hermaphrodite with mature seminiferous tubule (St) and ovarian follicles(Of), contain immature oocytes (Io) and the lumen spermatozoa $(\mathrm{Sz})$. 
MONTENEGRO, V. D.; OLIVARES, P. A. \& GONZÁLEZ, M. T. Hermaphroditism in marine mussel Perumytilus purpuratus (Lamarck, 1819), (Mollusca: Mytilidae). Int. J. Morphol., 28(2):569-573, 2010.

MONTENEGRO, V. D.; OLIVARES, P. A. \& GONZÁLEZ, M. T. Hermafroditismo en el chorito Perumytilus purpuratus (Lamarck, 1819), (Mollusca: Mytilidae). Int. J. Morphol., 28(2):569-573, 2010.

RESUMEN: Los bivalvos marinos son principalmente especies gonocoricas. Sin embargo, ocasionales especímenes hermafroditas pueden encontrarse. Una descripción histológica de dos (de 179) especímenes hermafroditas del chorito Perumytilus purpuratus (Lamarck, 1819) es registrada, los que fueron colectados en la bahía de San Jorge ( $24^{\circ} \mathrm{S}$ ). La baja proporción de hermafroditas de Perumytilus purpuratus sugiere que podría ser un fenómeno accidental, aun así otras posibles causas son discutidas en el presente estudio.

PALABRAS CLAVE: Bivalvos; Hermafroditismo; Perumytilus purpuratus.

\section{REFERENCES}

Afiati, N. Hermaphroditism in Anadara granosa (L.) and Anadara antiquata (L.) (Bivalvia: Arcidae) from central Java. Journal of Coastal Development, 10:171-9, 2007.

Bancroft, J. \& Stevens, A. Theory and practice of histological techniques. $3^{\text {rd }}$ Ed. London, Churchill Livingston, 1990.

Beninger, P. G. \& Le Pennec, M. Functional anatomy of scallops. In: Shumway, S. E. (Ed.) Scallops: Biology, Ecology and Aquaculture. Dev. Aquacult. Fish. Sci., 21:133-244, 1991.

Brink, L. A. Mollusca: Bivalvia. In: Shanks, A. L. (Ed.) An identification guide to the larval marine invertebrates of the Pacific Northwest. Corvallis, Oregon State University Press, 2001. pp.129-49.

Calvo, J.; Morriconi, E. \& Orler, P. Estrategias reproductivas de moluscos bivalvos y equinoideos. $E l$ mar Argentino y sus recursos pesqueros, 2:195-231, 1998.

Ceuta, L. O.; Boehs, G. \& Santos, J. J. B. Registro de hermafroditas em duas especies de bivalves dioicosTagelus plebeius (Lightfoot, 1786) e Iphigenia brasiliana (Lamarck, 1818) no estuario do Rio Cachoeira. Ilheus (BA). Caxambú, VIII Congresso de Ecologia do Brasil, 2007.

Chesman, B. S. \& Langston, W. J. Intersex in the clam Scrobicularia plana: a sign of endocrine disruption in estuaries?. Biol. Lett., 2:420-2, 2006.

Coe, W. R. Sexual differenciation in molluscks. I. Pelecypods. Quart. Rev. Biol., 18;154-64, 1943.

CREA, Centro regional de Estudios de Ambientales. Con- taminación por hidrocarburos en la zona costera de la ciudad de Antofagasta. Antofagasta, Universidad de Antofagasta, 2005.

deFur, P. L. Use and role of invertebrate models in endocrine disruptor research and testing. ILAR J., 45:484-93, 2004.

Delgado, M. \& Perez, A, C. Hermaphroditism in Ruditapes decussates (L.) (Bivalvia) from the Galician coastal (Spain). Sci. Mar., 66:183-5, 2002.

Field, I. A. Biology and economic value of the sea mussel Mytilus edulis. Bull. US Bur. Fish, 38:127-259, 1922.

Heller, J. Hermaphroditism in molluscs. J. Linn. Soc., 48:19-42, 1993.

Horiguchi, T.; Takiguchi, N.; Cho, H. S.; Kojima, M.; Kaya, M.; Shiraishi, H.; Morita, M.; Hirose, H. \& Shimizu, M. Ovo-testis and disturbed reproductive cycle in the giant abalone, Haliotis madaka: possible linkage with organotin contamination in a site of population decline. Mar. Environ. Res., 50:223-9, 2000.

Langston, W. J.; Burt, G. R. \& Chesman, B. S. Feminization of male clams Scrobicularia plana from estuaries in Southwest UK and its induction by endocrine-disrupting chemicals. Marine Ecology Progress Series, 333:173-84, 2007.

Lintelmann, J.; Katayama, A.; Kurihara, N.; Shore, L. \& Wendel, A. Endocrine disruptors in the environment (IUPAC Technical Report). Pure Appl. Chem., 75:63181, 2003.

Morton, B. Do the Bivalvia demonstrate environmentspecific sexual strategies? A Hong Kong model. J. Zool. (London), 223:131-42, 1991. 
MONTENEGRO, V. D.; OLIVARES, P. A. \& GONZÁLEZ, M. T. Hermaphroditism in marine mussel Perumytilus purpuratus (Lamarck, 1819), (Mollusca: Mytilidae). Int. J. Morphol., 28(2):569-573, 2010.

Mykhalov, A. T.; Torrado, M. \& Mendez, J. Sexual differentiation of reproductive tissue in bivalve molluscs: identification of male associated polypeptide in the mantle of Mytilus galloprovincialis Lmk. Int. J. Dev. Biol., 39:545-8, 1995.

Oehlmann, J. \& Shutlte-Oehlmann, U. Endocrine disruption in invertebrates. Pure Appl. Chem., 75:2207-18, 2003.

Olivares, P. A.; Jofre, M. D.; Álvarez, M. C. \& BustosObregón, E. Hermafroditismo funcional de la gónada de Fissurella crassa ( Mollusca: Fissurellidae). Int. J. Morphol., 27:509-14, 2009.

Ortiz, N. \& Re, M. E. First report of pseudohermaphroditism in cephalops. J. Mollus. Stud., 72:321-3, 2006.

Osorio, C. \& Bahamonde, N. Moluscos bivalvos en pesquerías Chilenas. Biol. Pesq., 3:93, 1968.

Paredes, C. \& Tarazona, J. Las comunidades de mitílidos del mediolitoral rocoso del departamento de Lima. Revista Peruana de Biología, 2:59-72, 1980.

Petridis, P.; Jha, A. N. \& Langston, W. J. Measurements of the genotoxic potential of (xeno-) oestrogens in the bivalve mollusc Scrobicularia plana, using the Comet assay. Aquat. Toxicol., 94:8-15, 2009.

Pipe, R. K. Ultraestrucutral and cytochemical study on interactions between nutrient storage cells and gametogenesis in the mussel Mytilus edulis. Mar. Biol., 96:519-28, 1987.

Salamanca, M. A.; Jara, B. \& Rodriguez, T. Niveles de Cu, $\mathrm{Pb}$, y $\mathrm{Zn}$ en agua y Perumytilus purpuratus en la Bahía San Jorge, norte de Chile. Gayana (Concepción), 68:5362, 2004.

Scarano, A. \& Ituarte, C. First report of a case of occasional hermaphroditism in Polyplacophora. J. Mollus. Stud., 75:91-2, 2009.

Villalon, G. R. Observaciones sobre la población de Perumytilus purpuratus (Lamarck) en Antofagasta, 1962-1963. (Mollusca, Lamellibranchiata,Mytilidae). Memoria para optar al título de profesor de Biología y Química, Universidad de Antofagasta, 1965.

Vinuesa, J. H. Sobre un caso de hermafroditismo en la cholga Aulacomya ater (Molina). Physis (Buenos Aires), 37:63$5,1977$.
Zar, J. H. Biostatistical analysis. 3rd Ed. New Jersey, Prentice Hall, 1996.

Correspondence to:

Alberto Olivares Paz.

Departamento de Acuicultura

Facultad de Recursos del Mar

Universidad de Antofagasta

Casilla 170, Antofagasta

CHILE

Email: aolivares@uantof.cl

Received: 26-03-2010

Accepted: 17-04-2010 
